AKRUAL 3 (1) (2011): 1-14 e-ISSN: 2502-6380

AKRUAL

Jurnal Akuntansi

http://fe.unesa.ac.id/ojs/index.php/akrl

\title{
ANALISIS PERBANDINGAN KINERJA KEUANGAN \\ BANK SWASTA NASIONAL DAN BANK PEMERINTAH YANG TERDAFTAR DI BURSA EFEK INDONESIA (BEI)
}

\author{
Sri Hastuti \\ Dyah Ratnawati $\mathrm{H}$ \\ Email: tutik_hastuti@yahoo.com \\ Artikel diterima: 30 Agustus 2011 \\ Terakhir direvisi: 29 Oktober 2011
}

\begin{abstract}
Performance or performance of bank is the image of reached achievement in banking operational in all aspect, covering monetary management of bank and ability of bank's assets had to yield profit efficiently, so bank can stay and compete in the middle of inflation distortion and policy of Bank Indonesia, hence the bank had to have up to standard performance or performance - condition health of bank determined by Bank Indonesia. This research aim to analyse and prove the difference flattens which isn't it in monetary performance Private National Bank and State Bank pursuant to ratioes of CAMEL. Sampel the used to amount to 12 banks, consist of 9 Private National Bank and 3 taken State Bank pursuant to Purposive Sampling with criterion enlist in Indonesia Stock Exchange (BEI), routine deliver financial statement, period of year 2005-2007.
\end{abstract}

Keywords: Monetary Performance of Bank, Ratio of CAMEL, Private National Bank, State Bank.

\section{PENDAHULUAN}

\section{Latar belakang}

Bank merupakan salah satu lembaga keuangan atau perusahaan yang bergerak di bidang keuangan. Pengertian bank menurut Undang-undang No.10 Tahun 1998 tentang perubahan atas Undang-undang No.7 Tahun 1992 tentang Perbankan, menyatakan bahwa bank adalah badan usaha yang menghimpun dana dari masyarakat dalam bentuk simpanan dan menyalurkannya kepada masyarakat dalam bentuk kredit dan atau bentuk-bentuk lainnya dalam rangka meningkatkan taraf hidup rakyat banyak. Salah satu sektor yang paling berperan dalam perekonomian nasional adalah sektor perbankan. Krisis moneter yang dimulai dengan merosotnya nilai rupiah terhadap dollar Amerika Serikat telah menghancurkan sendi-sendi ekonomi termasuk perbankan. Salah satu dampaknya adalah kolapsnya sejumlah bank-bank karena dianggap tidak layak lagi untuk meneruskan bisnisnya. 
Berdasarkan keputusan Menteri Keuangan, sebanyak 16 bank umum telah dicabut ijinnya pada tanggal 1 November 1997. Menyusul kemudian pada tanggal 13 Maret 1999 sebanyak 38 bank lain dinyatakan tidak boleh lagi meneruskan kegiatannya atau dilikuidasi. Agar suatu bank mampu bertahan dan bersaing dengan bank-bank lainnya, maka bank tersebut harus memiliki performance atau kinerja yang memenuhi syarat-syarat kesehatan bank yang ditentukan oleh Bank Indonesia. Menurut Abdullah (2004: 120), kinerja keuangan bank merupakan bagian dari kinerja bank secara keseluruhan. Kinerja atau performance bank secara keseluruhan ini adalah gambaran prestasi yang dicapai dalam operational perbankan dalam segala aspek. Analisis kinerja keuangan ini bermaksud untuk mengetahui keberhasilan pengelolaan keuangan bank dan mengetahui kemampuan bank dalam mendayagunakan aset-aset yang dimiliki untuk menghasilkan profit secara efisien, selain itu untuk memprediksi kesehatan suatu bank.

Dalam dunia perbankan Indonesia, alat analisis yang digunakan adalah CAMEL. Hal ini sesuai dengan Surat Keputusan Direksi Bank Indonesia (BI) Nomor 26/23/KEP/DIR tanggal 29 Mei 1993 tentang Tata Cara Penilaian Tingkat Kesehatan Bank, serta Surat Edaran Gubernur BI Nomor 26/5/BPPP tanggal 29 Mei 1993 tentang Tata Cara Penilaian Tingkat Kesehatan Bank Umum. Faktor CAMEL meliputi, permodalan (Capital), kualitas aktva produktif (Assets Quality), manajemen (Management), rentabilitas (Earnings), likuiditas (Liquidity). CAMEL tidak sekedar mengukur tingkat kesehatan bank, tapi digunakan sebagai indikator dalam menyusun peringkat dan memprediksi kebangkrutan bank. Menurut Nasser dan Aryati (2000: 112-113), tingkat kesehatan bank dapat dinilai dari beberapa indikator. Salah satu sumber utama indikator yang dijadikan dasar penilaian adalah laporan keuangan bank yang bersangkutan.

Analisis laporan keuangan sangat dibutuhkan untuk memahami informasi tentang laporan keuangan dalam mengevaluasi dan menginterpretasikan data laporan keuangan, salah satu caranya adalah dengan analisis rasio. Melalui analisis rasio ini, investor ataupun kreditor dapat mengukur kelemahan dan kekuatan yang dimiliki oleh suatu perbankan. Hasil analisis laporan keuangan dapat membantu dalam menginterpretasikan berbagai hubungan mengenai potensi keberhasilan perusahaan di masa mendatang. Untuk menilai kinerja keuangan perusahaan perbankan dapat diukur dengan rasio keuangan CAMEL, yaitu rasio yang digunakan untuk mengukur penampilan perbankan yang meliputi Capital Adequacy (Permodalan), Assets Quality (Kualitas Aktiva Produktif), Management of Risk (Manajemen Resiko), Earning Ability (Rentabilitas), Liquidity (Likuiditas). Variabel CAR, RORA, ROA, rasio kewajiban bersih call money terhadap aktiva lancar dan rasio kredit terhadap dana yang diterima signifikan untuk membedakan antara bank sehat dengan yang gagal dan NPM, BOPO tidak signifikan selama 5 tahun sebelum gagal (Aryati dan Manao, 2002).

Faktor permodalan penting dalam rangka pengembangan usaha dan menampung risiko kerugian. Faktor permodalan dinilai dengan Capital Adequacy Ratio (CAR). Ukuran CAR terbaik ditetapkan $8 \%$. Itu sebuah ketentuan baku dan 
lazim digunakan di dunia perbankan sedangkan untuk bobot CAR adalah 20\%. Faktor kuailtas aktiva produktif digunakan untuk mengukur tingkat pengelolaan aktiva produktif yang bermasalah dan pembentukan cadangan khusus untuk menampung kerugian akibat menurunnya kualitas akitva produktif, faktor ini diukur dengan Return On Risk Asset (RORA). Faktor manajemen diukur berdasarkan Net Profit Margin (NPM), hal ini merupakan inti dari pengukuran perbankan dimana seluruh kegiatan manajemen suatu bank pada akhirnya akan bermuara pada perolehan laba bank tersebut. Faktor rentabilitas digunakan untuk mengukur kemampuan bank dalam memperoleh laba dan tingkat efisiensi, baik dari kegiatan operasional maupun non operasional dalam suatu periode, faktor ini dinilai dengan menghitung Return of Assets (ROA) dan Beban Operasional terhadap Pendapatan Operasional (BOPO). Angka ROA dihitung berdasarkan perbandingan laba sebelum pajak dengan rata-rata asset total dengan standar terbaik 1,5\%. Untuk bobot ROA sebesar $10 \%$ dan BOPO $10 \%$. Faktor likuiditas merupakan faktor untuk mengukur tingkat kemampuan bank dalam melunasi kewajiban-kewajibannya pada saat ditarik atau jatuh tempo, faktor ini dinilai dengan Banking Ratio (BR). Perusahaan yang besar mempunyai komponen rasio yang berbeda dengan perusahaan kecil apabila rasio keuangan tersebut akan digunakan untuk memprediksi laba masa mendatang,dan Variabel CAR, RORA, ROA, rasio kewajiban bersih call money terhadap aktiva lancar dan rasio kredit terhadap dana yang diterima signifikan untuk membedakan antara bank sehat dengan yang gagal dan NPM, BOPO tidak signifikan selama 5 tahun sebelum gagal (Machfoedz, 1994 dalam Nasser dan Aryati, 2000).

Tujuan dari penelitian ini, yaitu untuk menganalisis dan membuktikan apakah terdapat perbedaan rata-rata yang signifikan dalam kinerja keuangan antara Bank Swasta Nasional dan Bank Pemerintah berdasarkan CAMEL.

\section{KAJIAN PUSTAKA}

\section{Pengertian dan Peranan Bank}

Bank sering kali disebut sebagai lembaga kepercayaan karena peran intermediasi keuangan yang dijalankan oleh bank terkait dengan penghimpunan dana dan penyaluran dana dalam masyarakat. Pengertian bank sebagaimana diatur dalam pasal 1 UU Nomor 7/1992 bahwa bank adalah badan usaha yang menghimpun dana dari masyarakat dalm bentuk simpanan, dan menyalurkannya kepada masyarakat dalam rangka meningkatkan taraf hidup rakyat banyak (Abdullah, 2004: 17). Melalui pengertian tersebut diatas mencerminkan dua peran bank baik sebagai financial intermediet maupun institute of economic development.

Bank dapat diartikan secara sederhana sebagai lembaga keuangan yang kegiatan usahanya menghimpun dana dari masyarakat dan menyalurkan kembali dana tersebut ke masyarakat serta memberikan jasa-jasa bank lainnya (Kasmir, 2003: 2). Melalui pengertian tersebut, kegiatan bank sebagai lembaga keuangan yaitu menghimpun dana dari masyarakat dalam bentuk simpanan dalam hal ini bank sebagai tempat menyimpan uang atau berinvestasi dengan harapan memperoleh bunga dari hasil simpanannya serta memudahkan untuk melakukan transaksi 
pembayaran, menyalurkan dana ke masyarakat dengan memberikan pinjaman (kredit) agar bank terhindar dari kerugian akibat tidak dikembalikannya pinjaman yang disalurkan bank.

Pengertian bank dari berbagai sumber lain dalam Dendawijaya (2001: 25), sebagai berikut :

1. "Bank adalah suatu badan usaha yang tugas utamanya sebagai lembaga perantara keuangan (financial intermediaries), yang menyalurkan dana dari pihak yang berkelebihan dana (idle fund/surplus unit) kepada pihak yang membutuhkan dana atau kekurangan dana (deficit unit) pada waktu yang ditentukan".

2. "Bank adalah suatu badan yang bertujuan untuk memuaskan kebutuhan kredit, baik dengan alat-alat pembayarannya sendiri atau dengan uang yang diperolehnya dari orang lain, maupun dengan jalan memperedarkan alat-alat penukar baru berupa uang giral" (G.M. Verryn Stuart).

3. "Bank adalah badan yang usaha utamanya menciptakan kredit" (Suyatno, 1996:1).

4. "Bank adalah suatu jenis lembaga keuangan yang melaksanakan berbagai macam jasa, seperti memberikan pinjaman, mengedarkan mata uang, pengawasan terhadap mata uang, bertindak sebagai tempat penyimpanan benda-benda berharga, membiayai perusahaan-perusahaan, dan lain-lain" (A. Abdurrachman, Ensiklopedia Ekonomi Keuangan dan Perdagangan).

\section{Jenis-jenis Bank}

Dalam praktiknya perbankan di Indonesia saat ini terdapat beberapa jenis perbankan seperti yang diatur dalam Undang-Undang Perbankan, namun kegiatan utama perbankan sebagai lembaga keuangan yang menghimpun dana dari masyarakat dan menyalurkan dana tidak berbeda satu sama lainnya. Karena luasnya mengenai lingkup perbankan, bank dibedakan menurut beberapa kelompok, berdasarkan fungsi dan peranannya (Ruddy 1996: 4), antara lain:

Menurut fungsinya

a. Bank umum adalah bank yang sumber utama dananya berasal dari simpanan masyarakat, terutama giro, tabungan dan deposito serta pemberian kredit jangka pendek dalam penyaluran dananya.

b. Bank sentral adalah bank yang merupakan badan hukum milik Negara.

c. Bank pembangunan adalah bank yang dalam pengumpulan dananya terutama berasal dari penerimaan simpanan dalam bentuk deposito serta komersial jangka panjang dan menengah.

d. Bank desa adalah kantor bank di suatu desa yang tugas utamanya adalah melaksanakan fungsi perkreditan dan penghimpunan dana dalam rangka program pemerintah memajukan sektor pedesaan serta peningkatan produksi pertanian, terutama pangan.

e. Bank Perkreditan Rakyat adalah kantor bank di kecamatan yang merupakan unsur penghimpunan dana masyarakat maupun menyalurkan dananya ke sektor pertanian atau pedesaan. 
Menurut kepemilikannya

a. Bank Pemerintah adalah bank yang seluruh modalnya berasal dari kekayaan Negara yang dipisahkan dan pendiriannya dibawah undang-undang tersendiri.

b. Bank Swasta Nasional adalah bank milik swasta yang didirikan dalam bentuk hukum perseroan terbatas dimana seluruh sahamnya dimiliki oleh WNI atau badan hukum di Indonesia.

c. Bank Koperasi adalah bank yang pengoperasiannya berlandaskan hukum koperasi dan anggotanya terdiri dari badan hukum koperasi.

d. Bank Swasta Asing adalah bank yang didirikan dalam bentuk cabang bank yang sudah ada di luar negeri.

e. Bank Pembangunan Daerah adalah bank yang pendiriannya berdasarkan peraturan daerah tingkat I dan sebagian besar sahamnya dimiliki oleh pemerintah daerah tingkat II di wilayah bersangkutan dan modalnya merupakan harta kekayaan milik pemerintah daerah yang dipisahkan.

\section{Laporan Keuangan Perbankan}

Setiap perusahaan, baik bank maupun non-bank pada periode tertentu akan melaporkan semua kegiatan keuangannya. Menurut Kasmir (2003:239), laporan keuangan bank menunjukkan kondisi keuangan bank secara keseluruhan dari laporan ini akan terbaca mengenai kondisi bank yang sesungguhnya termasuk kelemahan dan kekuatan yang dimiliki.

Menurut Myer dalam Munawir (2000:5), laporan keuangan adalah dua daftar yang disusun oleh akuntan pada akhir periode untuk suatu perusahaan. Kedua daftar itu adalah daftar neraca atau daftar posisi keuangan dan daftar pendapatan atau daftar rugi-laba. Pada waktu akhir-akhir ini sudah menjadi kebiasaan bagi perseroanperseroan untuk menambahkan daftar ketiga yaitu daftar surplus atau daftar laba yang tidak dibagikan (laba yang ditahan).

Menurut Abdullah (2004:106), laporan keuangan adalah sebagai bentuk pencatatan keuangan secara sistematis dan metodologis tentang posisi keuangan maupun hasil operasi keuangan perusahaan pada suatu periode waktu tertentu.

\section{Kinerja Keuangan Perbankan}

Menurut Abdullah (2004:120), kinerja keuangan perbankan merupakan bagian dari kinerja bank secara keseluruhan. Kinerja (performance) bank dicapai secara keseluruhan merupakan gambaran prestasi yang dicapai bank dalam operasionalnya, baik menyangkut aspek keuangan, pemasaran, penghimpun dan penyaluran dan teknologi maupun sumber daya manusia.

Berdasarkan pernyataan tersebut, maka kinerja keuangan bank merupakan gambaran kondisi keuangan bank pada suatu periode tertentu baik menyangkut aspek penghimpunan dana maupun penyaluran dana yang biasanya diukur dengan indikator kecukupan modal, likuiditas dan profitabilitas bank. 


\section{Analisis Kinerja Keuangan Perbankan dengan Metode CAMEL}

Menurut Abdullah (2004:120), analisis kinerja keuangan bank merupakan proses pengkajian secara kritis terhadap keuangan bank menyangkut review data, menghitung, mengukur, menginterprestasikan dan memberi solusi terhadap keuangan bank pada suatu periode tertentu. Analisis laporan keuangan yang umumnya disajikan di analisis berdasarkan tingkat kesehatan suatu bank, BI telah menetapkan sebuah ketentuan bahwa alat analisis yang digunakan adalah CAMEL. Hal ini sesuai dengan Surat Keputusan Direksi Bank Indonesia (BI) Nomor 26/23/KEP/DIR tanggal 29 Mei 1993 tentang Tata Cara Penilaian Tingkat Kesehatan Bank, serta Surat Edaran Gubernur BI Nomor 26/5/BPPP tanggal 29 Mei 1993 tentang Tata Cara Penilaian Tingkat Kesehatan Bank Umum.

Penilaian kinerja bank dengan teknik analisis CAMEL sebagai akronim Capiital, Assets Quality, Management, Earnings dan Liquidity dilakukan dengan langkah sebagai berikut:

1. Melakukan review data laporan keuangan (Neraca dan Laporan Laba-Rugi) dengan sistem akuntansi yang berlaku maupun penjelasan lain yang mendukung.

2. Menghitung angka rasio masing-masing aspek CAMEL.

3. Menghitung nilai kotor masing-masing rasio.

4. Menghitung nilai bersih masing-masing rasio dengan jalan mengalikan nilai kotor masing-masing dengan standart bobot masing-masing rasio.

5. Menjumlahkan nilai bersih rasio CAMEL.

6. Membandingkan hasil penjumlahan keseluruhan rasio CAMEL dengan standart Bank Indonesia.

Setiap rasio keuangan bank yang dibentuk memiliki tujuan yang ingin dicapai yang artinya tidak dijumpai batasan yang jelas dan tegas berapa banyak rasio yang terdapat pada setiap aspek CAMEL yang harus dianalisis, berikut ini analisis masingmasing aspek CAMEL (Faud dan Rustan, 2005:287) yaitu :

\section{Capital}

Penilaian didasarkan kepada permodalan yang dimiliki oleh suatu bank. Salah satu penilaiannya dengan menggunakan metode CAR (Capital Adequacy Ratio) yaitu dengan cara membandingkan modal terhadap aset beresiko.

2. Assets Quality

Penilaian didasarkan kepada kualitas aktiva produktif yang dimiliki oleh suatu bank yang diukur dengan 2 macam, yaitu :

a. Rasio aktiva produktif yang diklasifikasi terhadap aktiva produktif.

b. Rasio penyisihan penghapusan aktiva produktif terhadap aktiva produktif yang diklasifikasikan.

3. Management

Penilaian didasarkan kepada manajemen dibagi dalam 5 kelompok yaitu manajemen permodalan, manajemen aktiva, manajemen rentabilitas, manajemen likuiditas dan manajemen umum. Manajemen bank dinilai atas dasar 250 pertanyaan yang diajukan. 


\section{Earnings}

Penilaian ini didasarkan kepada rentabilitas suatu bank yaitu dengan melihat kemampuan suatu bank dalam menciptakan laba. Penilaian ini didasarkan atas 2 macam, yaitu :

a. Rasio laba terhadap total asset (Return on Assets).

b. Rasio beban operasional terhadap pendapatan operasional (BOPO).

5. Liquidity

Penilaian ini didasarkan untuk mengetahui kemampuan bank dalam memenuhi kewajiban segeranya. Perhitungan didasarkan kepada 2 macam rasio, yaitu :

a. Rasio jumlah kewajiban bersih Call Money terhadap aktiva lancar dan termasuk aktiva lancar adalah kas, giro pada BI, SBI, SBPU yang sudah diendos oleh bank lain.

b. Rasio antar kredit terhadap dana yang diterima oleh bank.

Berdasarkan penjelasan di atas maka dapat disusun kerangka konseptual sebagai berikut:

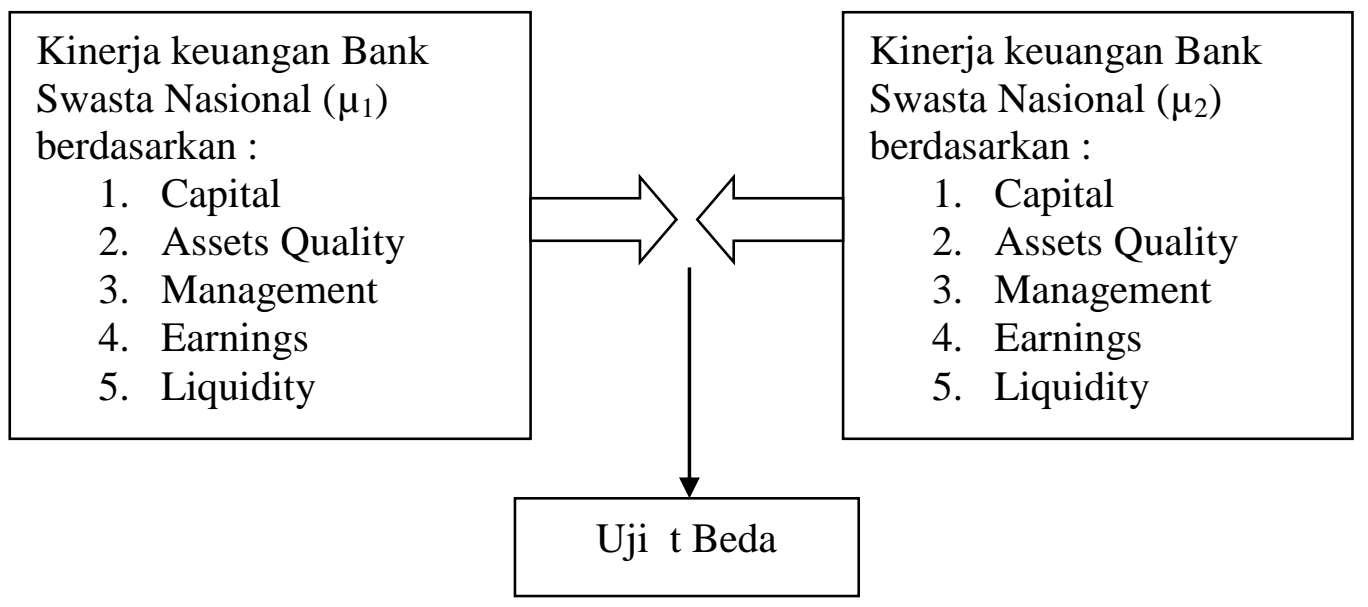

\section{Gambar 1. Kerangka Konseptual}

\section{Hipotesis} berikut:

Berdasarkan uraian yang telah dijelaskan maka dapat disusun hipotesis sebagai

H1: Bahwa terdapat perbedaan rata-rata yang signifikan antara kinerja keuangan

Bank Swasta Nasional dan Bank Pemerintah berdasarkan CAMEL. 


\section{METODE PENELITIAN}

\section{Definisi Operasional dan Pengukuran Variabel}

Pada penelitian ini kinerja keuangan merupakan gambaran prestasi yang dicapai bank dalam operasionalnya, (Abdullah 2004:120), yang dianalisis berdasarkan rasio keuangan, dengan indikator

a) Capital (Permodalan)

Kecukupan capital atau modal dianalisis dengan menggunakan rasio Capital Adequacy Ratio (CAR) dengan membandingkan capital atau modal dengan aset beresiko.

$$
C A R=\frac{\text { Equity }}{\text { Total Loans }+ \text { Securities }} \times 100 \%
$$

Pengukuran variabel ini dilakukan dengan menggunakan skala rasio dengan satuan pengukuran data adalah persentase.

b) Assets Quality (Kualitas Aset)

Kualitas aktiva produktif berkaitan dengan kelangsungan bank, dan manajemen bank dituntut untuk senantiasa memantau dan menganalisis kualitas aktiva produktif secara periodik (Sinungan,1994: 58).

Return On Risk Asset (RORA) yaitu suatu pengukuran besarnya resiko dan terjadinya kerugian yang mengakibatkan penurunan terhadap usaha bank yang bersangkutan sampai sejauh mana masih dapat ditutupi oleh modal.

$$
R O R A=\frac{\text { Earning Before Tax }}{\text { Total Loans }+ \text { Securities }} \times 100 \%
$$

Pengukuran variabel ini dilakukan dengan menggunakan skala rasio dengan satuanpengukuran data adalah persentase.

c) Management (Manajemen)

Manajemen merupakan kemampuan menjamin bank dalam memperoleh laba atau margin yang menunjukkan bahwa aktiva bisnis telah dikelola secara efisien oleh pihak manajemen. (Dendawijaya, 2001: 122 ).

Aspek manajemen dianalisis dengan menggunakan profit margin atau Net Profit Margin (NPM), yaitu rasio yang menggambarkan tingkat keuntungan (laba) yang diperoleh bank dibandingkan dengan pendapatan yang dikurangi dengan biaya kegiatan operasionalnya (Dendawijaya, 2001: 122).

$$
N P M=\frac{\text { Net Income }}{\text { Operating Income }} \times 100 \%
$$

Pengukuran variabel ini dilakukan dengan menggunakan skala rasio dengan satuan pengukuran data adalah persentase. 
d) Earnings (Rentabilitas)

Rentabilitas merupakan kemampuan bank untuk mendapatkan hasil usaha dalam kurun waktu tertentu yang dinyatakan dalam persentase aset dan modal (Muljono, 1900:54). Hasil usaha bank dapat berupa kerugian yang diderita dan laba yang diperolehnya, oleh karena itu rentabilitas merupakan indikator penting untuk melihat keberhasilan manajemen bank.

Earnings atau rentabilitas dianalisis dengan Return Of Assets (ROA) dan Beban Operasional (BOPO) adalah variabel yang digunakan untuk mengukur rentabilitas bank.

$$
\text { ROA }=\frac{\text { Laba sebelum pajak }}{\text { Total aktiva }} \times 100 \%
$$

Sumber : (Titik Aryati, $2002: 142$ )

$$
\text { BOPO }=\frac{\text { Total BebanOperasional }}{\text { Total PendapatanOperasional }} \times 100 \%
$$

Pengukuran variabel ini dilakukan dengan menggunakan skala rasio dengan satuan pengukuran data adalah persentase.

e) Liquidity (Likuiditas)

Likuiditas merupakan kemampuan bank untuk memenuhi kewajiban yang harus segera dipenuhi atau kewajiban jangka pendek.

Aspek likuiditas dianalisis dengan Banking Ratio (BR) yaitu salah satu variabel dari aspek likuiditas dengan melihat jumlah kredit terhadap jumlah pinjaman.

$$
\text { Banking Ratio }=\frac{\text { Total Loans }}{\text { Total Deposit }} \times 100 \%
$$

Pengukuran variabel ini dilakukan dengan menggunakan skala rasio dengan satuan pengukuran data adalah persentase.

\section{Teknik Penentuan Sampel}

Populasi dalam penelitian ini berjumlah 23 bank, terdiri dari 20 bank swasta dan 3 bank pemerintah yang terdaftar di Bursa Efek Indonesia antara tahun 20052007.

Teknik penentuan sampel yang digunakan dalam penelitian ini adalah purposive sampling yaitu teknik penarikan sampel nonprobabilitas yang berdasarkan ciri - ciri atau sifat khusus yang dimiliki oleh sampel, dan sampel tersebut merupakan representative dari populasi. (Sumarsono, 2001:52). Kriteria yang ditetapkan dalam pemilihan sampel penelitian ini sebagai berikut : 
1. Bank Swasta Nasional dan Bank Pemerintah yang terdaftar di Bursa Efek Indonesia (BEI).

2. Bank Swasta Nasional dan Bank Pemerintah yang terdaftar di Bursa Efek Indonesia (BEI) yang memiliki laporan keuangan selama periode 2005-2007.

3. Bank Swasta Nasional dan Bank Pemerintah yang rutin menyerahkan laporan keuangan.

4. Periode masing - masing bank swasta nasional dan bank pemerintah yang diteliti adalah 3 tahun, antara tahun 2005-2007.

Sampel dalam penelitian ini berjumlah 12 bank yang terdiri dari 9 Bank Swasta Nasional dan 3 Bank Pemerintah yang terdaftar di Bursa Efek Indonesia.

\section{Teknik Pengumpulan Data}

Dalam penelitian ini data yang diperlukan adalah data sekunder yaitu laporan keuangan perbankan berupa neraca dan laporan laba/rugi bank swasta nasional dan bank pemerintah yang diperoleh dalam bentuk Indonesia Captal Market Directory (ICMD) yang berada di Bursa Efek Indonesia.

\section{Teknik Analisis dan Uji Hipotesis}

Untuk menjawab permasalahan, tujuan dan hipotesis yang diajukan dalam penelitian, maka metode analisis yang digunakan adalah Independent Sample t-Test (uji t untuk dua sampel independen). Akan tetapi, terlebih dahulu dilakukan review atas data laporan keuangan dan menghitung rasio-rasio CAMEL seperti yang telah ditentukan dalam penelitian, setelah itu dilakukan pengujian Independent Sample t Test. Untuk mengolah data yang ada digunakan alat bantu komputer dengan program SPSS. 12.0, dimana pada output SPSS terdiri dari serangkaian pengujian yaitu Levene's Test For Equlity Of Variance yang digunakan untuk menguji varians populasi.

Jika probabilitas > 0,05 maka Ho diterima, sehingga dapat disimpulkan bahwa varians populasi adalah identik (homogen).dan sebaliknya Jika probabilitas $<0,05$ maka Ho ditolak, sehingga dapat disimpulkan bahwa varians populasi adalah berbeda (tidak homogen).

Berdasarkan hasil Levene's Test For Equality Of Variance nantinya akan diperoleh kesimpulan bahwa kedua varians populasi adalah homogen atau tidak homogen yang akan menentukan rumus t hitung pada tahap pengujian $t$ - Test For Equality Of Means yang digunakan untuk menguji rata - rata populasi.

Jika $\mathrm{t}$ hitung $>\mathrm{t}$ tabel atau probabilitas $<0,05$ maka $\mathrm{H} 0$ ditolak dan $\mathrm{Hi}$ diterima, jika $t_{\text {hitung }}<\mathrm{t}_{\text {tabel }}$ atau probabilitas $>0,05$ maka $\mathrm{H}_{0}$ diterima dan $\mathrm{H}_{\mathrm{i}}$ ditolak (Santoso 2001:96-99) 


\section{HASIL DAN PEMBAHASAN}

Hasil pengujian dengan menggunakan metode Independent Sample t-Test yang telah dilakukan, dapat diringkas sebagai berikut:

Tabel 1. Ringkasan Hasil Uji t

\begin{tabular}{|c|c|c|c|c|c|c|c|}
\hline \multirow[b]{2}{*}{ NO } & \multirow[b]{2}{*}{ RATIO } & \multicolumn{2}{|c|}{$\begin{array}{l}\text { Levene's Test For } \\
\text { Equality Of Variance }\end{array}$} & \multicolumn{3}{|c|}{$\begin{array}{c}T \text { - Test For Equality Of } \\
\text { Means }\end{array}$} & \multirow{2}{*}{ Keterangan } \\
\hline & & F hitung & Prob.(Sig) & $\begin{array}{c}\mathrm{t} \\
\text { hitung }\end{array}$ & t tabel & Prob.(sig) & \\
\hline 1 & CAR & 8,583 & 0,006 & 1,212 & 2,181 & 0,235 & Sama / identik \\
\hline 2 & RORA & 0,807 & 0,375 & $-0,645$ & 2,042 & 0,523 & Sama / identik \\
\hline 3 & NPM & 0,178 & 0,676 & $-0,366$ & 2,042 & 0,717 & Sama / identik \\
\hline 4 & ROA & 6,639 & 0,014 & $-0,95$ & 2,181 & 0,365 & Sama / identik \\
\hline 5 & BOPO & 0,197 & 0,66 & 0,339 & 2,042 & 0,737 & Sama / identik \\
\hline 6 & $\mathrm{BR}$ & 8,981 & 0,005 & 2,66 & 2,181 & 0,013 & Berbeda \\
\hline
\end{tabular}

Sumber : Data diola penulis

Berdasarkan tabel 1 di atas dapat disimpulkan bahwa terdapat satu variabel yang berbeda secara signifikan antara kinerja keuangan Bank Swasta Nasional dengan Bank Pemerintah berdasarkan Capital, Assets Quality, Management, Earnings, dan Liquidity (CAMEL) yang dianalisis dengan Independent Sample t-Test (uji t untuk dua sampel independen). Yang terlebih dahulu diuji dengan Levene's Test For Equlity Of Variance untuk menguji varians populasi dan t-Test For Equality Of Means untuk menguji rata-rata populasi. Variabel yang berbeda tersebut terletak pada rasio Liquidity yang diukur dengan Banking Ratio (BR).,dimana (sig) $<0,05$.

Analisis kinerja keuangan bank merupakan proses pengkajian secara kritis terhadap keuangan bank menyangkut review data, menghitung, mengukur, menginterpretasikan dan memberikan solusi terhadap keuangan bank pada suatu periode tertentu. Analisis laporan keuangan yang umumnya disajikan, di analisis berdasarkan tingkat kesehatan suatu bank. Bank Indonesia telah menetapkan sebuah ketentuan bahwa alat analisis yang digunakan adalah CAMEL.

Hasil pengujian menunjukkan bahwa tidak terdapat perbedaan rata-rata yang signifikan antara kinerja keuangan Bank Swasta Nasional dan Bank Pemerintah berdasarkan Capital, Assets Quality, Management, Earnings, tetapi terdapat perbedaan yang signifikan antara kinerja keuangan Bank Swasta Nasional dan Bank Pemerintah berdasarkan Liquidity.

Capital Adequacy Ratio (CAR), Return On Risk Asset (RORA), Net Profit Margin (NPM), Return Of Assets (ROA), Beban Operasional (BOPO) tidak menunjukkan perbedaan rata-rata yang signifikan antara Bank Swasta Nasional dan Bank Pemerintah. Hal ini dapat disebabkan adanya kenaikan BI Rate yang membawa dampak yang cukup luas meliputi kenaikan kredit macet, terganggunya fungsi intermediasi hingga penurunan spread perbankan yang cukup signifikan sebagai akibat dari inflasi yang melonjak tajam, sehingga pemerintah selaku otoritas fiskal dan Bank Indonesia selaku otoritas moneter sepakat untuk meredam inflasi dengan 
menaikkan BI Rate untuk menyerap kelebihan likuiditas rupiah di pasar dengan harapan agar masyarakat tetap percaya terhadap rupiah.

Sesuai Rapat Dewan Gubernur Bank Indonesia tanggal 5 Juni 2008, BI dan Pemerintah sepakat meredam lonjakan laju inflasi akibat kenaikan harga BBM dengan menaikkan BI Rate. Kenaikan BI Rate itu untuk mendorong masyarakat tetap percaya terhadap rupiah. Banking Ratio menunjukkan perbedaan rata-rata yang signifikan antara Bank Swasta Nasional dan Bank Pemerintah. Hal ini dapat disebabkan karena total kredit yang diberikan dibandingkan dengan total deposit yang diterima menurun. Hal ini bisa terjadi karena terdapat banyak kredit bank yang menunggak atau belum dilunasi pada saat jatuh tempo.

Tidak adanya perbedaan rata-rata NPM yang signifikan antara Bank Swasta Nasional dan Bank Pemerintah mungkin disebabkan adanya proporsionalitas antara Net Income dengan Operating Income. Bank Pemerintah akan mendapatkan net income-nya yang besar dan operating income-nya juga sebanding atau proporsional dengan net income-nya, demikian juga sebaliknya untuk Bank Swasta Nasional. Adanya proporsionalitas tersebut mungkin merupakan penyebab tidak adanya perbedaan rata-rata BOPO antara Bank Swasta Nasional dan Bank Pemerintah.

Sesuai penjelasan dalam penelitian Aryati dan Manao (2002), bahwa NPM dan BOPO antara bank yang sehat dan bank yang gagal tidak terdapat perbedaan yang signifikan karena adanya proporsionalitas antara Net Income dan Operating Income, bank yang sehat akan mendapatkan Net Income lebih besar dan Operating Income-nya juga sebanding atau proporsional dengan Net Income-nya, hal ini juga mungkin yang menyebabkan tidak adanya perbedaan rata-rata BOPO antara bank yang sehat dan bank yang gagal.

\section{SIMPULAN}

Berdasarkan analisis dan pembahasan mengenai "Analisis Perbandingan Kinerja Keuangan Bank Swasta Nasional dan Bank Pemerintah Yang Terdaftar Di Bursa Efek Indonesia", maka kesimpulan yang dapat diambil adalah tidak terdapat perbedaan rata-rata yang sinifikan antara kinerja keuangan Bank Swasta Nasional dan Bank Pemerintah berdasarkan Capital, Assets Quality, Management, Earnings, dan terdapat perbedaan rata-rata yang signifikan antara kinerja keuangan Bank Swasta Nasional dan Bank Pemerintah berdasarkan Liquidity. 


\section{DAFTAR PUSTAKA}

Abdullah, Faisal, 2004, Manajemen Perbankan: Teknik Analisis Kinerja Keuangan

Bank. Edisi Pertama, Penerbit Universitas Muhammdiyah, Malang.

Anonim, 2007, Standar Akuntansi Keuangan. Penerbit Salemba Empat, Jakarta.

Anonim, 2008, Pedoman Penyusunan Usulan Penelitian dan Skripsi Jurusan Akuntansi. Fakultas Ekonomi Universitas Pembangunan Nasional "Veteran" Jawa Timur.

-------, 2008, “Bank-Bank Dibakar Inflasi”, Info Bank, Edisi Juni no. 351, hal. 14.

--------, 2008, "Kriteria Penting Rating 125 Bank", Info Bank, Edisi Juni No. 351, hal. 18.

---------, 2008, “Tahan Bunga untuk Jaga Rupiah”, Surya, 08 November, hal. 5.

--------, 2008, "Perbankan Masih Sehat", Jawa Pos, 21 November, hal. 8.

-------, 2008, "Bunga Kredit Segera Turun”, Surya, 05 Desember, hal. 5.

-------, 2008, "BI Waspadai Kredit Macet”, Surya, 10 Desember, hal. 6.

--------, 2008, "NPL Bank Diprediksi Naik”, Surya, 16 Desember, hal. 5.

--------, 2008, "BI Turunkan Target Pertumbuhan Ekonomi”, Surya, 19 Desember, hal. 5 .

Aryati, Titik dan Hekinus Manao, 2002, Rasio Keuangan Sebagai Prediktor Bank Bermasalah di Indonesia, Jurnal Riset Akuntansi Indonesia, Vol. 5, No. 2, Mei, hal 137-147.

Dendawijaya, Lukman, 2001, Manajemen Perbankan. Penerbit Ghalia Indonesia, Jakarta.

Faud, Moh. Ramly dan M. Rustan, 2005, Akuntansi Perbankan: Petunjuk Praktis Operasional Bank. Edisi Pertama, Penerbit Graha Ilmu, Yogyakarta.

Kasmir, 2003, Dasar-Dasar Perbankan. Edisi Pertama, Penerbit PT. Raja Grafindo Persada, Jakarta.

Munawir, 2000, Analisa Laporan Keuangan. Edisi Keempat, Penerbit Liberty, Yogyakarta.

Mongid, Abdul, 2002, Accounting Data and Bank Failure: A Model for Indonesia, Jurnal Riset Akuntansi Indonesia, Vol. 5, No. 1, Januari, hal. 17-34.

Nasser, Etty M. dan Titik Aryati, 2000, Model Analisis CAMEL untuk Memprediksi Financial Distress pada Sektor Perbankan yang Go Publik, Jurnal Akuntansi dan Auditing Indonesia, Vol. 4, No. 2, Desember, hal. 111-127.

Setyaningsih, 2001, Faktor-Faktor Struktur Keuangan Bank yang Berpengaruh terhadap Kinerja Keuangan Perbankan pada Saat Krisis Ekonomi di Indonesia, Ventura, Vol. 4, No. 2, September, hal. 1-11.

Sugiyono, 1999, Statistik Untuk Penelitian. Penerbit CV. ALFABETA, Bandung.

Sumarsono, 2004, Metode Penelitian Akuntansi. Edisi Revisi, Surabaya.

Surifah, 2002, Kinerja Keuangan Perbankan Swasta Nasional Indonesia Sebelum dan Setelah Krisis Ekonomi, Jurnal Akuntansi dan Auditing Indonesia, Vol. 6, No. 2, Desember, hal. 23-42.

Wijaya, Andi, 2005, Analisis Kinerja Keuangan Perusahaan Perbankan Sebelum dan Sesudah Go Public di BES dengan Menggunakan Metode CAMEL, Skripsi, 
Fakultas Ekonomi, Universitas Pembangunan Nasional "Veteran" Jawa Timur, Surabaya.

Wijaya, Farried dan Soetatwo Hadiwigeno. 1999. Lembaga-Lembaga Keuangan dan Bank Perkembangan: Perkembangan, Teori dan Kebijaksanaan. Edisi Kedua, Penerbit BPFE, Yogyakarta. 